\title{
Adenoid Cystic Carcinoma of the Breast A case report and review
}

\author{
Major C J Phillips \\ $M B, C h B, F R C R$, RAMC
}

Surgical Division, Cambridge Military Hospital, Aldershot, Hants

SUMMARY: Adenoid cystic carcinoma of the breast is a malignant tumour of significant incidence with a better prognosis than histologically identical tumours occurring in other sites and as compared to other malignant tumours of the breast. The recognition of the tumour is important especially in the management of the individual patient but also in furthering understanding of growth, spread and biological behaviour of tumours.

\section{Introduction}

Adenoid cystic carcinoma of the breast is a rare tumour with an incidence of one to two cases per thousand mammary carcinomas(1-3) and a total of around one hundred and twenty reported in the world literature. It has identical histological features to adenoid cystic carcinoma of the salivary glands, and has to be differentiated pathologically from intra-ductal carcinomas with a cribriform pattern found in the breast, from which it has important distinguishing features; these are summarised in Table I. The widely divergent prognosis of these two mammary neoplasms makes their differentiation particularly important. The favourable prognosis of this tumour in the breast as compared to other sites remains unexplained. The UK cancer registry(4) records over twenty thousand cases of carcinoma of the breast each year, which would indicate an incidence of twenty to forty cases each year of adenoid cystic carcinoma of the breast; it seems likely from the currently reported series that a large proportion of these are not being recognised.

\section{Case Report}

A forty three year old white female presented with a five month history of a non-tender lump in the right breast, deep to the areola. There was a three year history of an intermittent bilateral odourless green discharge which varied with her menstrual cycle. It had never contained blood. Two mammograms had been performed in the past, the first nine years previously when the patient had given a history of breast tenderness and the second three years previously as part of an agerelated breast screening program. Both were reported as normal.

Having had 3 children, the patient had breast fed for six weeks, four months and six months respectively. Two trials on the oral contraceptive pill were abandoned because of breast tenderness, weight gain and hypertension. There was no past medical history of breast surgery nor a family history of breast disease.

Physical examination showed the right breast to contain an area of nodular breast tissue enclosing, supero-lateral and deep to the areola, a hard mass. The mobile mass was tender with normal overlying skin and no nipple retraction. There was no axillary or supraclavicular lymphadenopathy.

At incision biopsy a superficial macroscopically "nonsuspicious" cystic lesion was found, deep to which was a hard non-adherant mass, measuring $5 \mathrm{~cm} \times 2 \mathrm{~cm}$ occupying the subareolar area and superolateral quadrant. Histology was reported as adenoid cystic carcinoma of the breast, confirmed following a simple mastectomy with axillary clearance five days later. Figures 1 and 2 demonstrate the histology as found in this patient. There was no evidence of lymph node involvement but apocrine metaplasia and mild benign mammary dysplasia was present. No further treatment was given. The patient remains well and has no clinical recurrence of disease after five years follow-up.

\section{Discussion}

Adenoid cystic carcinoma occurs rarely in the breast; it occurs more frequently in the major and minor salivary glands and in mucous and mucoserous glands of other sites, giving rise to tumours in the lacrimal gland, external auditory canal, oesophagus, cervix uteri, prostate, Bartholin's gland and skin(1,2,5,6,7,8).

In extra-mammary sites it has, untreated, a characteristic slowly progressive course, with local recurrence, lymph node involvement and ultimately distant metastasis and death. When occurring in the breast it carries a favourable prognosis; only five cases have been reported causing death(9-12), of these the diagnosis has been questioned in two cases $(1,13)$ and documentation is incomplete in $\operatorname{two}(9,10)$. Metastases are uncommon, reported occurring to lymph nodes in two cases $(11,14)$ and more distant haematogenous spread most commonly to lung(15-17), often after a delay of several years. Koller et al report a solitary case to the brain after 12 years(18). Ten cases of local recurrence, nine following local excision, are reported $(3,5,8,17,19,20,21)$ accounting for simplc mastectomy being the treatment of choice. Deep tumour fixation is rare $(19,22)$ occurring in the presence of large tumour masses. The reported incidence of skin change ranges from none in $21 \operatorname{cases}(5)$ to five of nine 
Table 1

Comparison of Pathological Features of Adenoid Cystic Carcinoma and Intraductal Carcinoma

\begin{tabular}{cc}
\hline Adenoid Cystic Carcinoma & $\begin{array}{c}\text { Cribriform Intraductal } \\
\text { Carcinoma }\end{array}$ \\
\hline
\end{tabular}

\section{Biphasic Cellular Pattern}

present

-absent

cribriform or reticular

basophilic cells

- cuboidal cells

eosinophilic lining ducts

\section{Mucin Staining Pattern}

biphasic

- pseudocysts-Alcian blue + ve

- ducts PAS strong + ve

PAS ++

\section{Basophilic Cells Lining \\ Pseudocysts \\ - irregular cobblestone appearance}

\section{Cells Comprising Cribriform or Reticular Lobules \\ -small, uniform cells with small round or oval nuclei. \\ -1 or 2 small nucleoli \\ - sparse cytoplasm}

Mitotic Figures-infrequent
Necrotic Areas -infrequent
Histological pattern main-
tained at periphery on invasion
of stroma or fat

-frequent

- frequent

Histology develops

pattern of infiltrating

ductal carcinoma with

infiltration of

surrounding stroma or fat.

large with atypical prominent nucleoli abundent finely granular cytoplasm
Alcian blue weak +ve

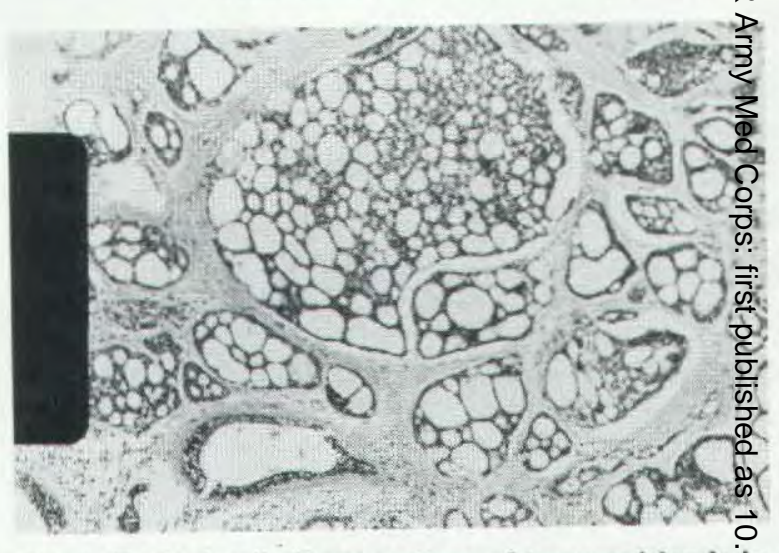

Fig 1. Typical cribriform pattern of tumour islands in connective tissue stroma. Basaloid cells with scargy cytoplasm surround cystic spaces.

Haemotoxylin and eosin $\times 20$. pleomorphic nuclei

cases(6); fungating tumours have been reported $(7,13,17,23)$. Nipple discharge has been reported only twice before; in each case the diagnosis of adenoid cystic carcinoma has been questioned by Azzopardi(2). In the case currently reported other breast pathology was present, the histology being reported as apocrine metaplasia and benign mammary dysplasia.

Associated tumours are reported in a number of cases; Cavanzo and Taylor(5) state that the prognosis of the patient is that of the other tumour. Associated carcinoma is reported by a number of authors $(1,6$, , 声, $24,25,26)$. Peters and Wolff(16) report a synchron(\$1s contra-lateral intra-ductal carcinoma. Also reported कie fibroadenoma(6,8,19), sclerosing adenosis $(6,27)$ a a cystic spaces lined with metaplastic epithelium(17).

Mammography of cases of adenoid cystic carcino?a of the breast reported by three authors produces $\frac{70}{80}$ concensus of opinion as to its 'typical' appearance ( 27,28).

Five authors $(11,21,24,29,30)$ report cases in mide patients. 


\section{Conclusion}

A further case of this unusual but significant tumour is reported. Adenoid cystic carcinoma of the breast is important by virtue of its behaviour when related to its site and its histology. Adenoid cystic carcinoma of the breast, and of the skin, has a significantly better prognosis than when the histologically identical tumour occurs in other sites. Prioleau et al(7) postulate both anatomical and biochemical explanations for this. As the prognosis is good with only rare cases of distant metastasis $(9,11,17,18,19)$ even following excision, local recurrence or presentation with large locally invasive tumours, it is hard to support an anatomical basis for the differences, especially in view of the apparent frequency of metastasis observed with other breast tumours. The biological and biochemical features of this tumour then gain importance and require further study to evaluate how these are related to relative biological aggressiveness.

Simple mastectomy is advocated as the treatment of choice by most authors $(5,7,11,24,27,28,30)$ to minimise the risk of local recurrence.

\section{Acknowledgements}

I would like to thank Colonel M Payne L/RAMC for his permission to report this case and his help and encouragement in its preparation. Further thanks are due to Lieutenant Colonel Myron $\mathrm{E}$ Whitehead of the Clinical Pathology Service, Walter Reed Army Medical Center, Washington D.C.

\section{REFERENCES}

1. ANTHONYP P, JAMES P D. Adenoid cystic carcinoma of the breast prevalence, diagnostic criteria and histogenesis. $J$ Clin Pathol 1975; 28:647-655.

2. Azzopardi J G. Problems in breast pathology, W B Saunders Ltd, London, 1979, 335-339.

3. Cammoun H, Contessi G, Rousse J. Les adenocarcinomes cylindromateaux du sein. Ann Anat Pathol 1972; 17:143.

4. Cancer Statistics Registrations for England and Wales. Office of Population Censuses and Surveys. 1983, H MSO.

5. Cavanzo F J, Herbert B T. Adenoid cystic carcinoma of the breast. An analysis of 21 cases. Cancer 1969; 24:740745.

6. Galloway J R, Woolner l B, Clagetr O T. Adenoid cystic carcinoma of the breast. Surg Gynecol Obstet 1966; 122:1278-1294.

7. Prioleau P G, Santa Cruz D J, Buettner J B, Bauer W C. Sweat gland differentiation in mammary adenoid cystic carcinoma. Cancer 1979; 433: 1752-1760.

8. Qizilbash A H, Patterson M C, Oliveira K F. Adenoid cystic carcinoma of the breast. Light and electron microscopy and a brief review of the literature. Cancer 1977; 101:302-306.

9. NAYER H R. Cylindroma of the breast with pulmonary metastasis. Dis Chest 1957; 31:324-327.

10. O'Kell R T. Adenoid cystic carcinoma of the breast. Missouri Med 1964; 61:855-858.

11. VERANI R R, VAN Der Bel-Kahn J. Mammary adenoid cystic carcinoma with unusual features. Am J Clin Pathol 1973; 39:653-658.

12. Sumpio B E, Jennings T A, Sullivan P D. et al. Adenoid cystic carcinoma of the breast. Ann Surg 1987; 205:295-301

13. Steinman A, Pepus M, Mcswain G. Adenoid cystic carcinoma of the breast. South Med J 1978; 71:851-853.

14. Wells C A, Nicoll B, Ferguson D J. Adenoid cystic carcinoma of the breast; a case with axillary lymph node metastatis. Histopathology 1986; 10:415-424.

15. ELSENER B. Adenoid cystic carcinoma of the breast. Pathol Eur 1970; 5:357-364.

16. Lim S K, Kovi J, WARner O G. Adenoid cystic carcinoma of the breast with metastatis; a case report and review of the literature. J Natl Med Assoc 1979; 71: 329-330.

17. Peters G N, Wolff M. Adenoid cystic carcinoma of the breast. Cancer 1983; 52:680-686.

18. Koller M, Ram Z, Findler G, Lipshitz M. Brain metastasis; a rare manifestation of adenoid cystic carcinoma of the breast. Surg Neurol 1986; 26:470-472.

19. LUSTED D. Structural and growth patterns of adenoid cystic carcinoma of the breast. Am J Clin Pathol 1970; 54:419425 .

20. WILSON W B, Spell J P. Adenoid cystic carcinoma of the breast: a case with recurrence and regional metastatis. Ann Surg 1967; 166: 861-864.

21. Woyke S, Damagala W, Olszewski W. Fine structure of mammary adenoid cystic carcinoma. Polish Med J 1970; 9:1140-1148.

22. O'Connor T, Cornell D, Lohman H, SOyer M T. Adenoid cystic carcinoma of the breast; a case report. Ala J Med Sci 1982; 19:17-18.

23. Lerner A G, Molnar J J, adams Y G. Adenoid cystic carcinoma of the breast. Am J Surg 1974; 127:585-587.

24. Friedman B A, Oberman H A. Adenoid cystic carcinoma of the breast. Am J Clin Pathol 1970; 54:1-14.

25. Gricouroff G, Zajdela A, Bendana B N. Le cylindrome mammare. Bull Cancer 1964; 51:277-282.

26. Koss L G, Brannan C D, Ashikari R. Histological and ultra structural features of adenoid cystic carcinoma of the breast. Cancer 1970; 26:1271-1279.

27. Hopkins G B, Tullis R $\mathbf{H}$. Adenoid cystic carcinoma of the breast. Calif Med 1972;117:9-11.

28. JaWORSKI R C, KNeAle K L, SMITH R C. Adenoid cystic carcinoma of the breast. Postgrad Med J 1983; 59: 48-51.

29. Ferlito A, Di Bonito L. Adenoid cystic carcinoma of the male breast: report of a case. Am Surg 1974; 40:72-75.

30. HJorth S, Magnusson P H, Blomouist P. Adenoid cystic carcinoma of the breast; report of a case in a male and review of the literature. Acta Chir Scand 1977; 143:155158. 